\title{
PENERAPAN METODE BERPIKIR KREATIF "HAPPY" UNTUK MENDISAIN KARYA VISUAL ART ARSITEKTUR
}

\author{
Happy Indira Dewi ${ }^{1)}$, Zulfitria ${ }^{2)}$, R. Andi Ahmad Gunadi ${ }^{3)}$ \\ ${ }^{1}$ Magister Teknologi Pendidikan, Universitas Muhammadiyah Jakarta \\ email: h.indiradewi@umj.ac.id \\ ${ }^{2}$ Magister Teknologi Pendidikan, Universitas Muhammadiyah Jakarta \\ email: fzulfitria@umj.ac.id \\ ${ }^{3}$ Magister Teknologi Pendidikan, Universitas Muhammadiyah Jakarta \\ email: aagunadi@umj.ac.id
}

\begin{abstract}
This research is a preliminary study, from a study of Creative Learning Models for Gifted Visual Art Children. Architecture is included in the applied 3-dimensional visual art criteria. The research problem is how to apply creative thinking models by Happy that are used by architectural students in designing architectural works. The research method used is descriptive kualitative method. The aim of the research is to know the thinking process of architectural students in the work, which will be used as a reference to develop visual art architectural creative thinking methods at the level of children. The results of this study are the application of creative thinking models by Happy can produce works that meet creative criteria, namely flexibility, originality, elaboration, fluency and completeness.
\end{abstract}

Keywords: methods, thinking, creative, architectural work, visual art

Abstrak

Penelitian ini adalah penelitian pendahuluan, dari penelitian Model Pembelajaran Kreatif Untuk Anak Berbakat Visual Art. Arsitektur termasuk dalam kriteria visual art 3 dimensi yang bersifat terapan, Permasalahan penelitian adalah bagaimana penerapan model berpikir kreatif "Happy" yang di gunakan oleh mahasiswa arsitektur dalam mendisain karya arsitektur. Metode penelitian yang digunakan adalah metode kualitatif deskriptif. Tujuan penelitian adalah mengetahui proses berpikir mahasiswa arsitektur dalam berkarya, yang akan digunakan sebagai acuan mengembangkan metode berpikir kreatif visual art arsitektur pada tingkat anak-anak. Hasil penelitian ini adalah penerapan model berpikir kreatif Happy dapat menghasilkan karya yang memenuhi kriteria kreatif, yaitu fleksibilitas, orisnilitas, elaborasi, kefasihan dan kelengkapan.

Kata kunci: metode, berpikir, kreatif, arsitektur, visual art

\section{PENDAHULUAN}

Metode berpikir kreatif ditemukan oleh Happy pada tahun 2014 setelah melakukan penelitian selama 2,5 tahun. Metode ini dinamakan Metode Berpikir Kreatif "Happy". Metode ini terbukti dapat mempermudah mahasiswa arsitektur peserta Perancangan Arsitektur 1 (selanjutnya disingkat PA) dan PA 2 dalam menghasilkan karya (dalam kasus ini karya arsitektur) secara kreatif. Karya kreatif adalah karya yang memenuhi indikator kreativitas yaitu, lengkap, lancar, orisinil, fleksibilitas, orisinil, dan elaborasi. Metode Berpikir Kreatif "Happy", dalam penelitian ini akan diujicobakan kembali kepada mahasiswa arsitektur yang berbeda dan tingkat kesulitan yang berbeda, yaitu pada PA 5 (mata kuliah ini berjenjang dari PA 1, PA 2, PA 3, PA 4, PA 5, dan PA 6).

Saat ini pembelajaran yang berkaitan dengan visual art untuk anak-anak sangat minim. Pembelajaran kesenian (yang berkaitan dengan visual art) diajarkan hanya sebatas kemampuan guru umum mengajar saja (Zulfitria. dkk: 2018). Padahal visual art sangat diperlukan di era modern ini untuk mengasah kreativitas dan rasa manusia sejak dini, untuk menjaga keseimbangan manusia dalam menghadapi era 4.0 , yang semuanya identik dengan otomatisasi. 
Permasalahan dalam penelitian ini adalah ingin mengetahui kehandalan Metode Berpikir Kreatif "Happy" untuk mahasiswa dengan tingkat kesulitan PA yang berbeda.

Jika dalam penelitian ini, metode tersebut terbukti lagi dapat menghasilkan karya yang memenuhi indikator kreativitas, yaitu lengkap, lancar, orisinil, fleksibilitas, orisinil, dan elaborasi, metode ini akan disederhanakan menjadi Metode Berpikir Kreatif "Happy" yang digunakan sebagai acuan untuk anak-anak belajar berkarya visual art 3 dimensi (arsitektur), dengan tingkat kesulitan yang disesuaikan usia anak-anak.

Oleh karena itu, perlu diadakan penelitian yang menguji kembali kehandalan Metode Berpikir Kreatif "Happy" berkaitan dengan bagaimana proses berpikir mahasiswa arsitektur dalam berkarya, sebelum dijadikan sebagai acuan dasar untuk mengembangkan metode berpikir kreatif untuk berkarya yang lebih sederhana untuk anak-anak.

\section{KAJIAN LITERATUR}

Berpikir adalah proses yang dinamis yang prosesnya berawal dari pembentukan pengertian, pembentukan pendapat dan penarikan kesimpulan (Suryabrata: 2013). Proses yang dinamis ini merupakan aktivitas akal dan rohani yang berlaku pada seseorang yang tersusun dengan teratur, karena adanya kecenderungan keinginan untuk mengetahui dan mengalami, supaya dapat melahirkan makna, fakta dan pemahaman. Dalam proses berpikir tersebut terjadi hubungan antara stimulus dan respon dari suatu kegiatan kognitif tingkat tinggi (higher level cognitive) (Iskandar: 2009. Proses berpikir berjalan dinamis, yang mengerahkan segala kemampuan akal dan rohani, adapun hasilnya adalah makna, fakta dan pemahaman yang bersifat tetap.

Dalam berpikir manusia menggunakan otak sebagai alat untuk berpikir. Pembelajaran dengan menerapkan strategi sesuai dengan cara kerja otak dapat membuat belajar menjadi lebih dinamis (Connel; 2005). Guilford dalam Munandar mengatakan berpikir kreatif dapat dimiliki seseorang melalui kategori berpikir divergen, dengan melatih aspek-aspek kelancaran, kelenturan, orisinilitas dan elaborasi kepada peserta didik (Munandar: 2012). Lawson mengatakan cara berpikir otak secara konvergen dan divergen. Cara berfikir konvergen adalah memerlukan pola berpikir tunggal untuk mengembangkan ide dan lebih mudah dilakukan karena berurusan dengan akal. Sedangkan cara berpikir divergen adalah berpikir dengan melihat berbagai kemungkinan-kemungkinan yang baru, berurusan dengan imajinasi, dan pembatasan persoalan sangat ketat (Lawson: 2005). Pembelajaran yang menerapkan cara berpikir otak secara divergen dan konvergen akan dapat menghasilkan ide-ide kreatif yang kemudian memutuskan ide yang akan menjadi dasar pembuatan karya.

Sousa mengatakan bahwa berpikir kreatif adalah kemampuan menggunakan pemikiran divergen untuk mendalami dan menemukan solusi alternatif bagi masalahmasalah yang muncul, tanpa diperkirakan sebelumnya (Sousa: 2012). Kegiatan berarsitektur sangat memerlukan kreativitas. karena berkaitan erat dengan kegiatan mencipta atau menggagas. Sularto menambahkan berpikir kreatif bagi seorang arsitek adalah berusaha menciptakan suatu karya yang diakui dan mempunyai makna, dan dapat memuaskan dan menyenangkan pemakai bangunan tersebut, sifat kreativitas dari individu seorang arsitek dapat memberi pengaruh yang khas dan unik terhadap lingkungannya (Tutut dkk: 2001).

Selanjutnya Pradono menggambarkan proses kreatif seorang arsitek memerlukan waktu yang panjang dan berliku-liku, memiliki keindahan tersendiri, ide dan gagasan besar dalam bangunan tersebut terdiri dari sekumpulan ide-ide kecil yang banyak sekali (Pradono: 2010). 
Proses berpikir kreatif merupakan dasar keahlian untuk mempermudah proses penciptaan karya arsitektur. Proses ini juga dapat mempermudah mahasiswa melakukan proses transformasi konsep ke dalam karya arsitektur, sebagai proses yang tersulit dalam mata kuliah perancangan arsitektur.

Dari uraian di atas dapat disimpulkan pentingnya berpikir kreatif bagi seorang calon arsitek, oleh karena itu berpikir kreatif hendaknya diaplikasikan dalam pembelajaran perancangan arsitektur dalam bentuk model desain berpikir kreatif untuk transformasi konsep ke dalam karya arsitektur untuk mata kuliah Perancangan Arsitektur.

Konsep berpikir kreatif arsitektur terbentuk dari konsep transformatik Lie Tjun Tjie yaitu proses berpikir untuk menghasilkan temuan baru, dalam prakteknya proses berpikir dari inkubasi ke iluminasi tidak dapat diprediksi dan dikendalikan, proses ini membantu menjalankan imajinasi dan menuntun peserta didik untuk melakukkan transformasi secara perlahan. Setiap tahap

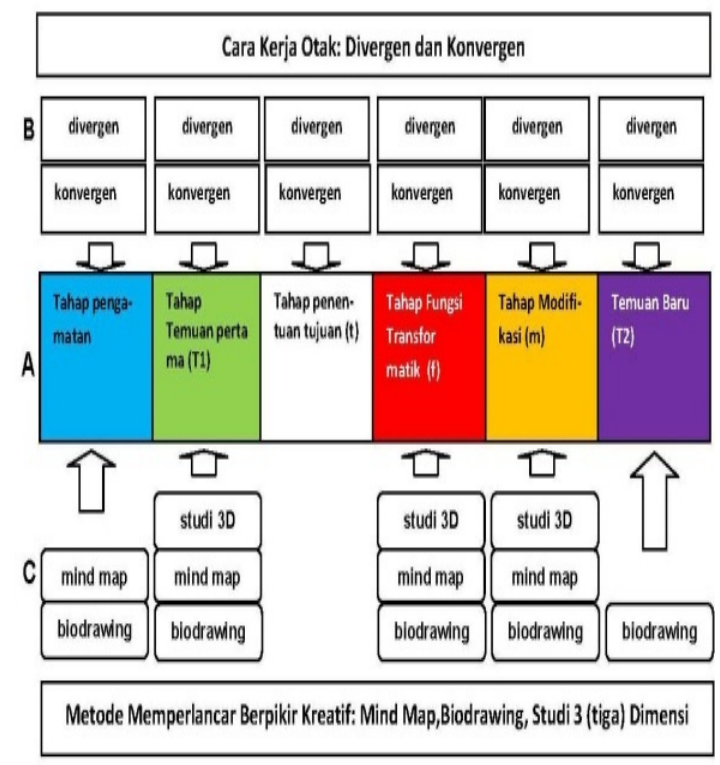

Gambar 1. Model Konsep Berpikir Kreatif "Happy" Untuk Menghasilkan Karya (Sumber: Jurnal Teknologi Pendidikan. Vol. 17, No. 2, Agustus 2015 )

menggunakan cara kerja otak divergen konvergen dan memanfaatkan metode memperlancar berpikir kreatif. Kolaborasi proses transformatik Lie Tjun Tjie (A), cara kerja otak berpikir kreatif (B) dan metode mempercepat berpikir kreatif $(\mathrm{C})$.

Jurus biodrawing untuk merangsang otak visual dan salah satu media yang tepat untuk mengungkapkan imajinasi, dengan aktivitas menggambar yang dapat membantu pengembangan pada otak manusia (Olivia: 2010). Maket model dalam bentuk 3 dimensi untuk menunjang dan menumbuhkan ketrampilan mahasiswa lebih kreatif dalam kegiatan mendisain, yang pada akhirnya dapat meningkatkan efektifitas dalam pembelajaran, dan tugas-tugas mahasiswa lebih baik, dan kelulusan mahasiswa lebih baik juga (Azmi: 2007).

Mind map adalah cara untuk menempatkan informasi ke dalam otak dan mengambil informasi dari/ke luar otak. Mind map mencatat dengan kreatif, efektif, dan memetakan pikiran. Mind map menggunakan warna, memiliki struktur alami yang memancar dari pusat, menggunakan garis lengkung, simbol, kata, dan gambar yang sesuai dengan satu rangkaian aturan yang sederhana, mendasar, alami, sesuai dengan cara kerja otak dan mengalihkan informasi yang panjang menjadi diagram warna-warni sangat teratur, mudah diingat dan dapat bekerja secara alami (Buzan: 2010).

Metode ini menggunakan berbagai cara berpikir yang dikemas untuk mempermudah mahasiswa menghasilkan karya arsitektur, dalam sebuah model yang dinamakan Metode Berpikir Kreatif "Happy". Adapun untuk penelitian Model Pembelajaran Kreatif untuk Anak Berbakat Visual Art, metode ini akan disederhanakan dan disesuaikan dengan usia anak-anak.

\section{METODE PENELITIAN}

Metode penelitian yang digunakan adalah kualitatif deskriptif, pengamatan dengan observasi terhadap mahasiswa arsitektur yang sedang melaksanakan metode berpikir kreatif "Happy", 
kemudian dijabarkan secara tahap demi tahap. Subyek penelitian adalah, 75 mahasiswa arsitektur yang sedang mengikuti pelajaran PA 5 di Jurusan Arsitektur Fakultas Teknik Universitas Muhammadiyah Jakarta.

\section{HASIL DAN PEMBAHASAN}

Tugas adalah membuat desain bangunan mixed-use building, bangunan mixed use building terdapat di pusat kota dan dapat merupakan bagian dari CBD. Beberapa fungsi dalam satu bangunan yang dinamakan mixed use building, bangunan yang memiliki beberapa fungsi yang berbeda dan saling terintegrasi untuk memperpendek dan mempercepat jalur sirkulasi manusia dan kendaraan dalam berkegiatan.Peserta Studio Perancangan Arsitektur Tingkat Lanjut, terdiri dari 75 mahasiswa. Pada pembelajaran ini diterapkan Model Berpikir Kreatif Happy, untuk membimbing mahasiswa memecahkan permasalahan disain.

Berikut ini adalah hasil pengamatan terhadap pelaksanaan penerapan terhadap model berpikir kreatif Happy (gambar 1). Tahap pengamatan, mahasiswa berpikir divergen dengan melakukan pengamatan terhadap ciri-ciri bangunan mixed used building secara literatur (gambar 2). Lalu membuat dengan mind map uraian yang berkaitan dengan lokasi tapak bangunan, aktivitasmanusia, bangunan (tampak, struktur dan bentuk) kegiatan ini dilakukan dengan biodrawing (menggambar langsung dengan tangan). Kemudian berpikir konvergen dengan melakukan penarikan kesimpulan dari hasil dari studi literatur dan survei lapangan tersebut.

Tahap temuan pertama, mahasiswa survei ke lokasi tapak yang sebenarnya (gambar 3). Mencari temuan berupa data lokasi tapak, data aktvitas pengguna, data struktur bangunan dan tampilan bangunan. Berpikir divergen menggali data, mengidentifikasi data dan berpikir konvergen menyusun data. Kemudian survei ke bangunan mixed-used building untuk merasakan pengalaman ruang dari luar dan dalam jenis bangunan ini.

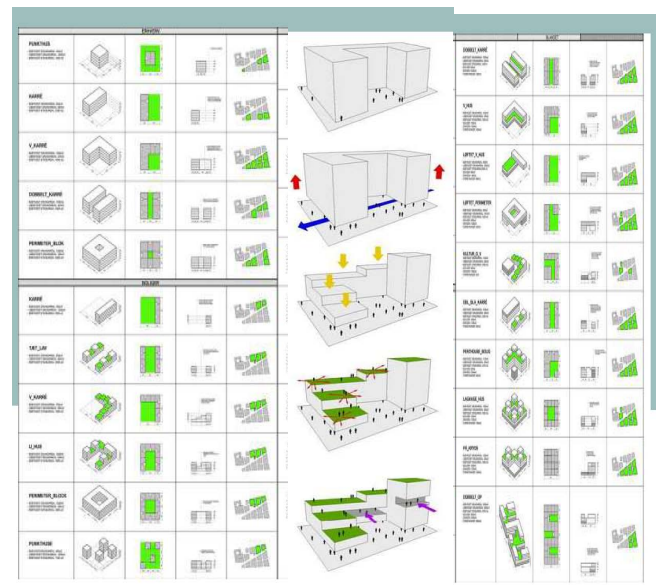

Gambar 2. Studi referensi bentuk dan struktur massa bangunan dengan literatur dengan mind map (Sumber: Happy)

Tahap penentuan tujuan, setelah data literatur dan lapangan terpenuhi mulailah terlihat apa dan bagaimana mendisain bangunan mixed used building, kemudian berpikir divergen dengan
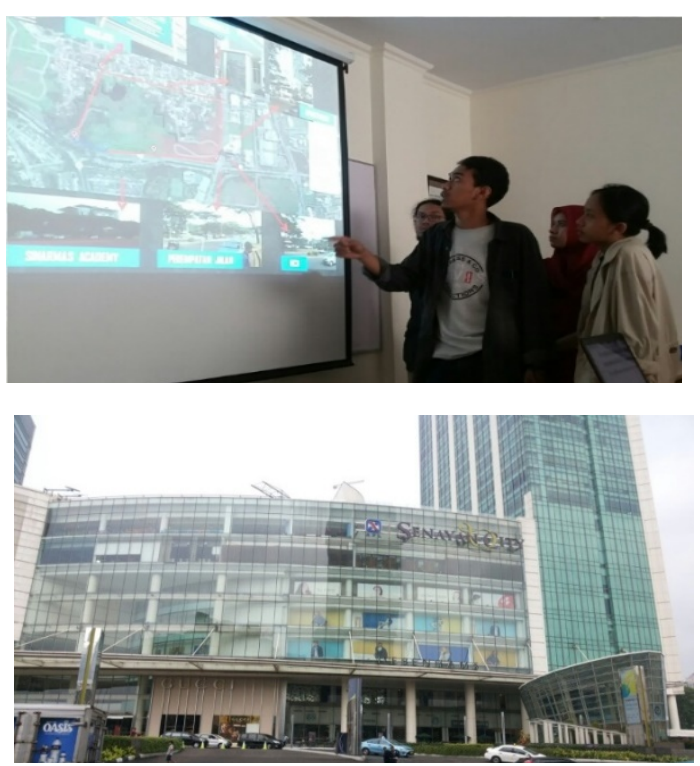

Gambar 3. Pelaporan kelompok hasil survei ke lokasi tapak di Bumi Serpong Damai dan Kegiatan Survei mahasiswa ke contoh mixedused building Senayan City Kelompok Wahyu (Sumber:Happy)

beberapa alternatif tujuan, lalu ditetapkan satu konsep dasar dalam menciptakan 
karya. Contoh konsep dasar adalah seperti karya mahasiswa bernama Hendro A Rasyid menetapkan konsep dasar dengan metaphora bangunan diibaratkan magnet. Konsep dasar ini mendasari transformasi konsep tapak, konsep ruang dan konsep bangunan menjadi karya.

Tahap transformatik, konsep dasar sebagai landasan konsep-konsep tapak, ruang dan bangunan untuk mentransformasi menjadi karya bangunan (gambar 4). Pertama, proses transformatik untuk mendapatkan penataan zona bangunan, zona parkir dan sirkulasi kendaraan dan sirkulasi manusia.
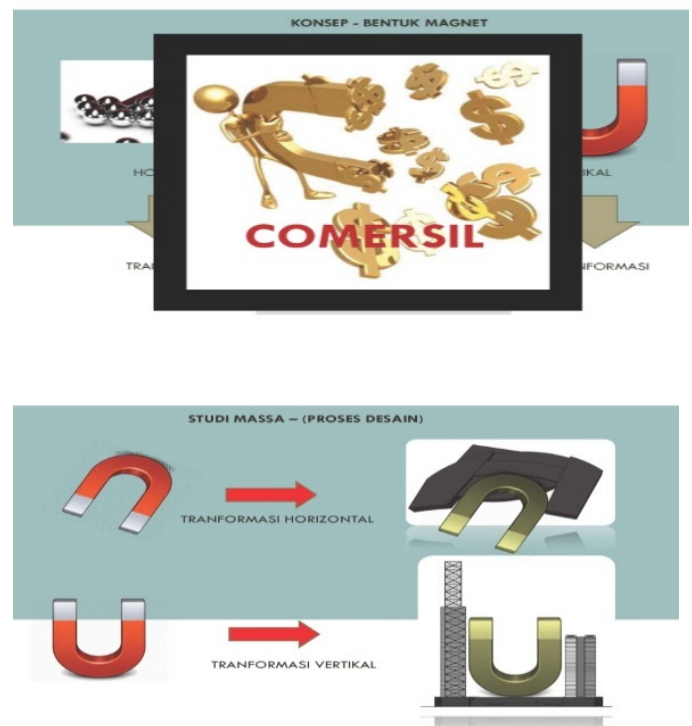

Gambar 4. Konsep dasar bangunan menggunakan metafora dari bentuk magnit karya Hendra A Rasyid (Sumber:Happy)

Mahasiswa dibimbing untuk melakukan pengamatan terhadap lokasi tapak bangunan mixed used building. Pengamatan dilakukan langsung di lokasi yaitu Bumi Serpong Damai Tangerang. Secara berkelompok melakukan pengamatan dan pengukuran langsung di lapangan dengan mengamati bentuk site, arah mata angin, potensi lingkungan di sekelilingnya. Pada kegiatan belajar pengamatan terhadap lingkungan ini menggunakan metode mind map dan biodrawing. Metode mind map, untuk memetakan kondisi yang ada di sekitar lokasi dengan menggambarkan lokasi tapak, dan memberikan penjelasan kondisi di sekitar tapak terdapat apa saja. Metode biodrawing, dengan menggambarkan apa saja yang terdapat di sekitar lokasi tapak. Dari analisis lokasi tapak ini didapatkan kesimpulan penataan zona bangunan, zona parkir dan sirkulasi kendaraan dan sirkulasi manusia (gambar 5).

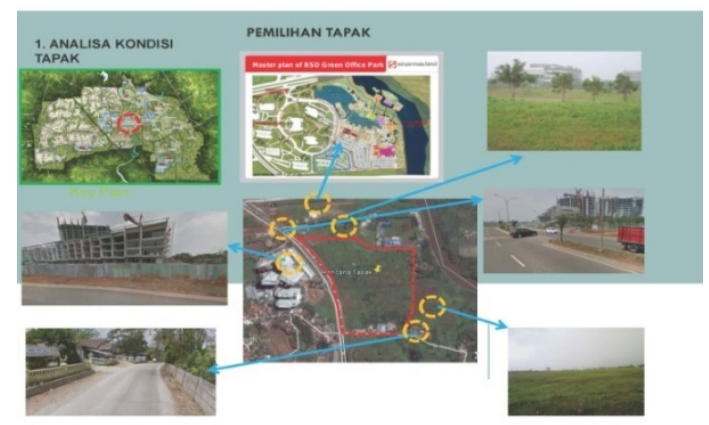

Gambar 5. Penataan zona bangunan, zona parkir dan sirkulasi kendaraan dan sirkulasi manusia dengan menggunakan mind map dan biodrawing, kemudian di gambarkan dengan CAD karya Hendra A Rasyid (sumber:Happy)

Kedua, proses transformatik untuk mendapatkan bentuk massa bangunan, menggunakan teknologi visual art 3 dimensi. Caranya setelah mendapatkan penataan zona bangunan, zona parkir dan sirkulasi kendaraan dan sirkulasi manusia. Letakkan massa dengan bahan plastisin atau streroform yang telah memiliki luasan sesuai dengan kebutuhan ruang. Kemudian Untuk menemukan bentuk massa bangunan, letakkan pada zona yang bangunan. Bentuk di sempurnakan dengan curter tanpa mengurangi besaran ruangan. Sampai mendapatkan bentuk massa yang sesuai dengan lokasi tapak bangunan dan lingkungannya. Kemudian barulah digambarkan ke laptop secara 3 dimensi. Dengan memberikan warna yang berbeda, warna coklat untuk bangunan zona kantor, warna merah untuk zona mall dan warna kuning untuk hotel. 
Ketiga, proses transformatik untuk mendapatkan bentuk denah, sistem struktur bangunan dan fasade bangunan. Mahasiswa dibimbing untuk berpikir divergen dengan mencari contoh beberapa bangunan mixed used, dengan menggunakan mind map.

Pada titik pusat mind map diberikan lingkaran besar yang merupakan tempat disain baru akan dihasilkan. Kemudian gambar-gambar contoh tersebut ditelisik

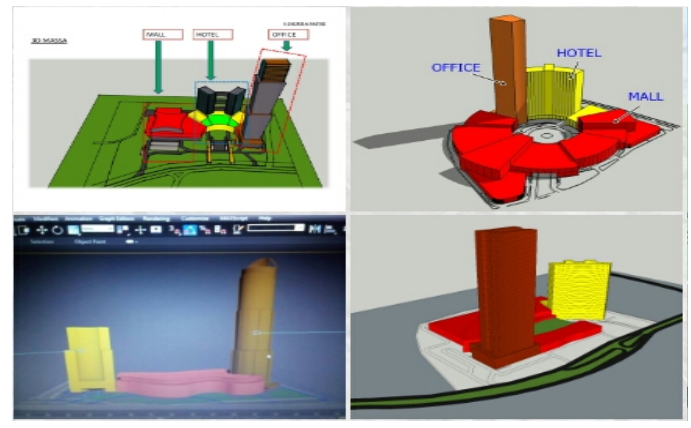

Gambar 6. Setiap bagian dari mixed-used building diberikan warna berbeda untuk mempermudah mahasiswa dan dosen menganalisis perletakan zona kantor (coklat), zona mall (merah)dan zona hotel (kuning) karya beberapa peserta Perancangan Arsitektur Lanjut (sumber:Happy)

gambar denah dan mahasiswa mendapatkan konsep denah. Dari beberapa struktur dan fasade bangunan didapatkan konsep struktur dan fasade bangunan. Cara berpikir ini digunakan untuk mencari bentuk denah, bentuk tampak dan bentuk struktur dan massa bangunan (gambar 6).

Tahap Modifikasi, melakukan modifikasi dengan mengintegrasikan keenam hasil penataan meliputi penataan massa bangunan, penataan parkir, penataan bentuk massa bangunan, penataan bentuk denah, pengaturan sistem struktur dan pembuatan bentuk tampak bangunan. Proses modifikasi berlangsung terus menerus sampai keenam komponen di atas dapat melebur menjadi desain baru.

Tahap Temuan Baru, setelah ditemukan disain baru sesuai dengan tugas yang diberikan oleh dosen, barulah mahasiswa melakukan penggambaran

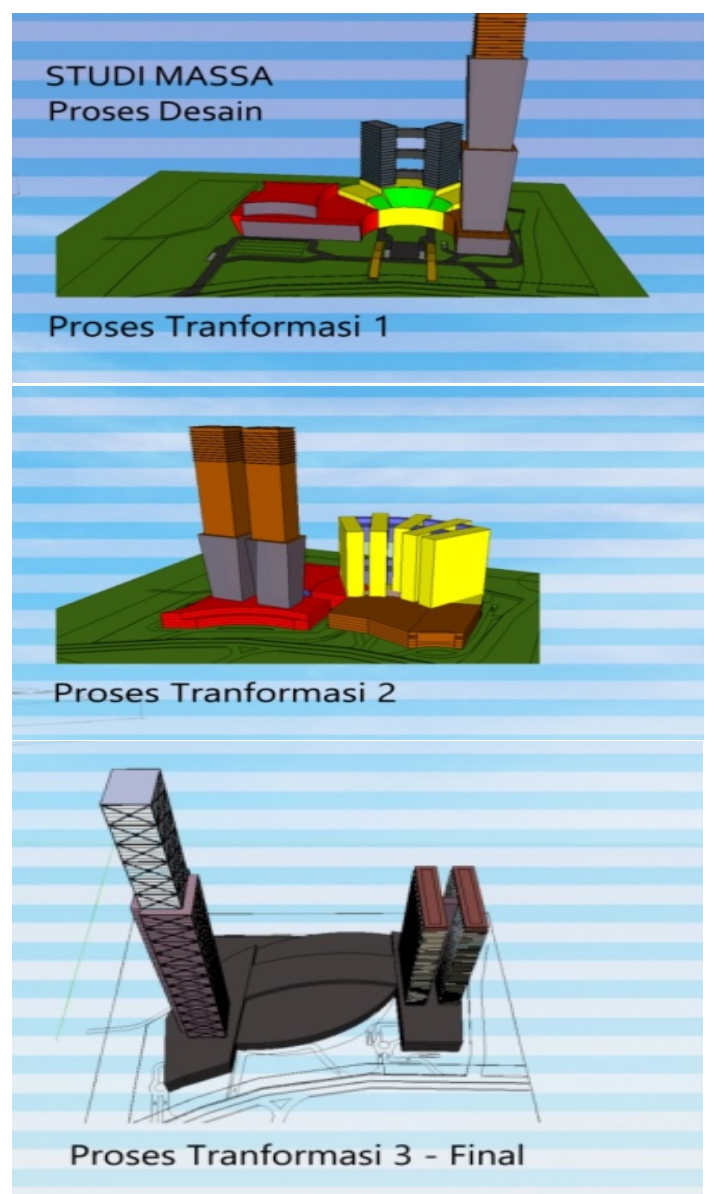

Gambar 7. Proses transformasi dari bentuk massa awal menjadi massa yang final setelah di cek dengan luasan bangunan, perletakan ruangan, parkir dan sirkulasi kendaraan dan manusia Karya Hendra A Rasyid. (Sumber: Happy)

dengan autocad, menjadi gambar site plan, denah, tampak, potongan, dan tiga dimensi (gambar 7).

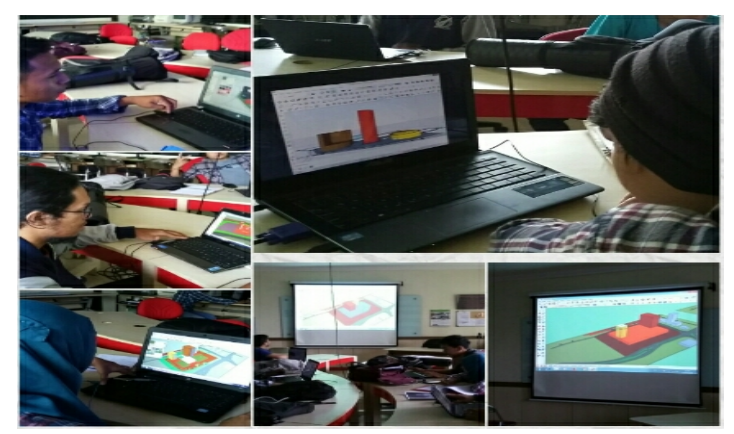

Gambar 8. Suasana Proses berlangsungnya transformasi ide menjadi karya menggunakan berbagai media dan metode yang kompleks (Sumber : Pribadi) 


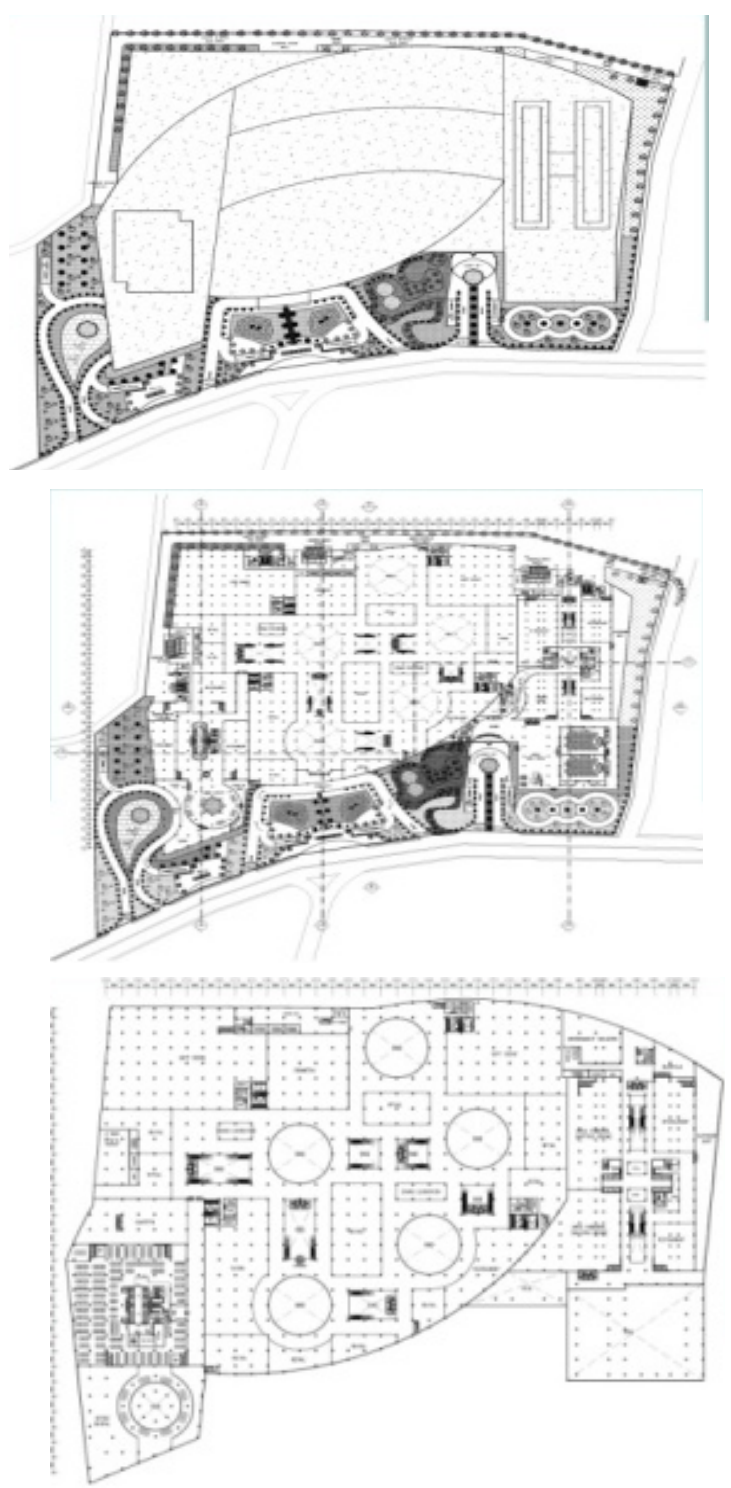

Setiap langkah dari tahap pengamatan, tahap temuan pertama, penentuan tujuan, tahap transformatik, tahap modifikasi dan tahap temuan baru, menggunakan selalu mengaktifkan cara kerja otak secara divergen dan konvergen. Misalnya yaitu mencari berbagai macam bentuk denah, tampak, jenis struktur bangunan, (berpikir divergen), kemudian di analisis dan dipilih yang terbaik (berpikir secara konvergen) dikerucutkan dan disimpulkan dengan mencari bentuk denah, tampak, jenis struktur bangunan yang sesuai dengan tugas yang diminta (Gambar 9).

\section{KESIMPULAN}

Hasil penelitian ini adalah model berpikir kreatif "Happy" dapat diterapkan untuk menghasilkan karya yang orisinil
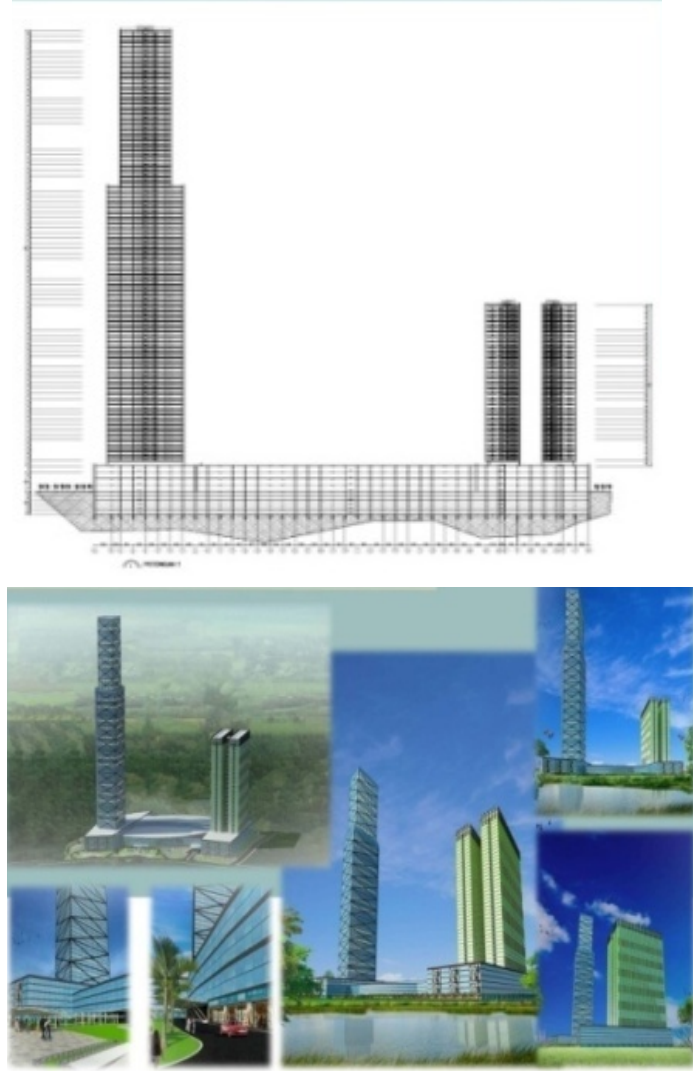

Gambar 9. Hasil Karya menggunakan berbagai media dan metode yang kompleks karya Hendra A Rasyid (Sumber : Happy)

berbeda satu dengan lainnya, dan dapat mewujudkan ide menjadi karya dengan tingkat kelulusan yang tinggi $93 \%$. Beberapa langkah dari Metode Berpikir Kreatif Happy diprediksi dapat diterapkan dan digunakan untuk anak-anak, oleh karenanya untuk penelitian berikutnya akan dilakukan penyederhanaan Model Berpikir Kreatif "Happy" untuk usia anakanak, sebagai embrio generasi visual art arsitektur Indonesia yang handal di masa depan.

\section{Acknowledgment}

Alhamdulillah atas terselesaikannya penelitian ini. Terimakasih ditujukan kepada Direktorat Riset dan Pengabdian Masyarakat Direktorat Jenderal Penguatan Riset dan Pengembangan Teknologi, dan 
Pendidikan Tinggi sebagai penyandang dana utama, sesuai dengan Kontrak Penelitian Tahun Anggaran 2018 Nomor: 006/KM/PNT/2018, Tanggal 06 Maret 2018. Terimakasih kepada semua komponen Universitas Muhammadiyah Jakarta (pimpinan, teman sejawat, mahasiswa dan karyawan) sebagai institusi tempat peneliti bekerja yang telah membantu dan memberi kesempatan berkarya. Terimakasih kepada keluarga besar peneliti dan semua pihak yang sangat mendukung kegiatan penelitian ini.

\section{REFERENSI}

Azmi, M. Fathien. 2007. Metode Pembelajaran Yang Tepat Untuk Mata Kuliah Berbasis Studio Pada Jurusan Arsitektur :Pengembangan Proses Pembelajaran Interaktif Pemanfaatan Media Maket Model Pada Studio Perancangan Arsitektur Pada Student Centre Learning". Prosiding Semiloka Nasional Pendidikan Arsitektur di Jakarta.

Buzon, Toni. 2010. Buku Pintar Mind Map. Jakarta: Gramedia.

Connel,J. Diane. 2005. Brain-Based Strategies to Reach Every Learner.New York: Scholastic.

Dewi, Happy Indira. 2015. Pengembangan Strategi Pembelajaran Berlandaskan Cara Berpikir Kreatif Untuk Membuat Karya Arsitektur. Jurnal Teknologi Pendidikan. Vol. 17, No. 2, Agustus 2015

Dewi, Happy Indira, Zulfitria, R. A. A. Gunadi. 2018. Kontribusi Pembelajaran Visual Art Dalam Meningkatkan Kreativitas Anak-Anak Di Perbatasan Desa Dan Kota Untuk Menghadapi Era Industri 4.0. Makalah belum diterbitkan pada International Conference on Rural Studies in Asia Unnes Semarang.

Iskandar. 2009. Psikologi Pendidikan: Sebuah Orientasi Baru.Ciputat: GP Press.
Lawson, Bryan. 2005. How Designers Think. Oxford: Architectural Press

Munandar, Utami Munandar. Pengembangan Kreativitas Anak Berbakat. Jakarta: Rineka Cipta.

Olivia, Femi. 2010. Meroketkan Kekuatan Otak Kanan denganJurus Biodrawing. Jakarta: PT. Elek Media Komputindo.

Pradono, Budi. 2010. Budi Pradono: In Process. Jakarta: Budi Pradono Architechs.

Semiawan, Conny.R. 2009. Kreativitas dan Keberbakatan : Mengapa, Apa, dan Bagaimana. Jakarta: Indeks.

Sousa, David A. 2012. Bagaimana Otak Belajar, terjemahan Siti Mahyuni. Jakarta: PT.Indeks

Suryabrata, Sumadi. 2013. Psikologi Pendidikan. Depok: Raja Grafindo

Tutut, Ahmad dan Junianto. 2001. Karya Arsitektur Undagi Robi Sularto. Malang: Pusat Studi Tata Lingkungan \& Bentang Alam Jurusan Arsitektur Universitas Merdeka

Zulfitria, Happy Indira Dewi, R. A. A. Gunadi. 2018. Peran Guru Di Era Millinium Terhadap Perkembangan Kreativitas Siswa Di Daerah Perbatasan Desa. 